\title{
EFEKTIFITAS ASUHAN KEPERAWATAN KELUARGA TERHADAP TINGKAT KEMANDIRIAN KELUARGA MENGATASI MASALAH KESEHATAN DI KELUARGA
}

\author{
Agrina ${ }^{1}$, Reni Zulfitri \\ ${ }^{1}$ Dosen Keperawatan Komunitas Program Studi IImu Keperawatan \\ Universitas Riau
}

\begin{abstract}
ABSTRAK
Tujuan penelitian adalah untuk mengetahui pengaruh pemberian asuhan keperawatan keluarga terhadap kemandirian keluarga dalam mengatasi masalah kesehatan di keluarga di wilayah kerja Puskesmas Rumbai Pekanbaru. Desain yang digunakan adalah kuasi eksprimen one group pretest-posttest design. Jumlah sampel sebanyak 50 keluarga yang memenuhi kriteria inklusi, dengan teknik pengambilan sampel puposive sampling. Analisa data pada penelitian ini bersifat univariat dan bivariat (uji $T$ dependen). Hasil penelitian menunjukkan bahwa adanya pengaruh yang signifikan pemberian asuhan keperawatan keluarga terhadap tingkat kemandirian keluarga dalam mengatasi masalah kesehatan keluarga ( $p$ value $=$ $0,000)$. Penting sekali perawat Puskesmas melakukan asuhan keperawatan pada keluarga dalam bentuk kunjungan rumah guna membantu keluarga mengatasi masalah kesehatan yang ada di keluarga sehingga status kesehatan keluarga dapat meningkat.
\end{abstract}

Kata kunci: asuhan, keperawatan, keluarga, kemandirian, masalah kesehatan

\section{PENDAHULUAN}

Keluarga merupakan unit terkecil dalam masyarakat, yang merupakan entry point dalam upaya mencapai kesehatan masyarakat secara optimal. Tercapainya kesehatan keluarga, akan mewujudkan tercapainya peningkatan derajat kesehatan masyarakat. Dengan demikian, kesehatan keluarga merupakan kunci utama pembangunan kesehatan masyarakat. Friedman (2003) mengatakan bahwa keluarga merupakan salah satu aspek penting dalam keperawatan. Hal ini disebabkan karena keluarga sebagai suatu kelompok yang dapat menimbulkan, mencegah, mengabaikan atau memperbaiki masalah-masalah kesehatan di dalamnya. Selain itu, keluargalah yang tetap berperan sebagai pengambil keputusan dalam memelihara kesehatan para anggotanya. Dengan demikian, dapat disimpulkan bahwa keluargalah yang menjadi faktor penentu sehat-sakitnya anggota keluarga, yang akan berdampak pada munculnya berbagai masalah kesehatan anggota keluarga. 
Vol 7, No 2, Oktober 2012: 81 - 89

Masalah kesehatan yang muncul di keluarga tentunya sangat tergantung kepada bagaimana keluarga menjalankan fungsi perawatan kesehatan keluarga. Penelitian sebelumnya oleh Zulfitri R, Agrina, dan Herlina (2011) di Kelurahan Umban Sari Wilayah kerja Puskesmas Rumbai memperlihatkan bahwa 51\% keluarga mampu melaksanaan fungsi perawatan kesehatan keluarga, sedangkan 49\% keluarga tidak mampu melaksanaan fungsi perawatan kesehatan keluarga. Hasil penelitian ini memperlihatkan bahwa sebagian keluarga telah mampu melaksanakan fungsi perawatan kesehatan keluarga mulai dari keluarga mengenal masalah, keluarga mengambil keputusan untuk merawat anggota keluarga yang sakit, melakukan perawatan anggota keluarga yang sakit, memodifikasi lingkungan rumah, dan keluarga memanfaatkan pelayanan kesehatan yang ada.

Hasil penelitian ini juga memperlihatkan bahwa hampir sebagian keluarga (49\%) belum mampu melaksanaan fungsi perawatan kesehatan keluarga. Kondisi ini tentunya dapat memperparah masalah kesehatan yang sedang dialami anggota keluarga yang sakit. Sebagai contoh penyakit hipertensi pada anggota keluarga, yang apabila keluarga tidak mampu menjalankan fungsi perawatan kesehatan keluarga pada anggota keluarga yang sakit tersebut tentunya penyakit hipertensi akan terus berlanjut dan semakin berat.

Purnomo.H (2009) mengatakan bahwa hipertensi yang terjadi dalam jangka waktu lama dan terus menerus bisa memicu stroke, serangan jantung, gagal jantung dan merupakan penyebab utama gagal ginjal kronik. Misbach (2005) menyampaikan bahwa di Indonesia, stroke menyerang 36\% lansia, khusus untuk stroke haemoragik disebabkan oleh penyakit hipertensi yang tidak terkontrol. Menurut WHO (2001), jumlah kematian karena penyakit jantung koroner yang disebabkan oleh hipertensi yang tidak terkontrol adalah mencapai 42,9\%.Sehingga dapat diketahui bahwa tingginya angka komplikasi adalah akibat dari penanganan hipertensi yang tidak efektif atau tidak terkontrol di rumah. Hal ini terkait erat dengan pelaksanaan fungsi perawatan kesehatan di dalam keluarga dalam merawat anggota keluarga yang mengalami hipertensi.

Masalah kesehatan di keluarga lainnya yang juga banyak ditemukan, seperti: gizi kurang, infeksi saluran nafas atas (ISPA), gastristis, dan lain-lain. Berdasarkan data Depkes RI (2009), di Indonesia diketahui 157.000 bayi meninggal dunia per tahun, atau 430 bayi meninggal per hari, dan angka kematian balita di Indonesia juga masih cukup tinggi, yaitu mencapai 46 dari 1.000 balita setiap tahunnya. Bila dirinci, 82 
kematian balita ini mencapai 206.580 balita per tahun, dan 569 balita per hari. Tingginya angka kematian pada bayi dan balita, selain sering disebabkan karena kondisi kesehatan anak secara kongenital dan faktor lingkungan yang tidak sehat, juga sangat dipengaruhi oleh kurangnya pengetahuan dan kemampuan keluarga melaksanakan fungsi perawatan kesehatan keluarga di rumah.

Dalam upaya meningkatkan kemampuan keluarga melaksanakan fungsi perawatan kesehatan keluarga di rumah, maka penting bagi keluarga untuk memahami dan melaksanakan lima tugas kesehatan keluarga. Friedman (2003) menyampaikan bahwa lima tugas kesehatan keluarga meliputi: pertama, keluarga diharapkan mampu mengenal berbagai masalah kesehatan yang dialami oleh seluruh anggota keluarga. Kedua, keluarga mampu memutuskan tindakan keperawatan yang tepat dalam mengatasi berbagai masalah kesehatan yang dialami oleh seluruh anggota keluarga. Ketiga, keluarga mampu melakukan perawatan yang tepat sehari-hari di rumah. Keempat, keluarga dapat menciptakan dan memodifikasi lingkungan rumah yang dapat mendukung dan meningkatkan kesehatan seluruh anggota keluarga. Kelima adalah keluarga diharapkan mampu memanfaatkan pelayanan kesehatan untuk mengontrol kesehatan dan mengobati masalah kesehatan yang tidak dapat diselesaikan sendiri oleh keluarga.

Lima tugas kesehatan keluarga tersebut baru dapat dilaksanakan dengan baik dan benar apabila keluarga mendapatkan upaya pembinaan dan bimbingan dalam menjalankan lima fungsi perawatan kesehatan keluarga. Upaya pembinaan dan bimbingan kepada keluarga agar tercapai kemandirian keluarga dalam mengatasi berbagai masalah kesehatan di keluarga dapat dilakukan melalui penerapan asuhan keperawatan keluarga.

Menurut Depkes RI (2006), ada beberapa criteria kemandirian keluarga berrdasarkan tingkat kemandirian, diantaranya: menrima petugas kesehatan, menerima pelayanan kesehatan sesuai rencana keperawatan keluarga, keluarga tahu dan dapat mengungkapkan masalah kesehatannya dengan benar, memanfaatkan fasilitas pelayanan kesehatan sesuai anjuran, melakukan tindakan keperawatan sederhana sesuai anjuran, melakukan tindakan pencegahan secara aktif, dan melakukan tindakan promotif secara aktif.

Hasil penelitian Suhartini R (2006) menunjukkan adanya pengaruh secara signifikan faktor kesehatan terhadap kemandirian orang lanjut usia, berdasarkan hasil uji 
Vol 7, No 2, Oktober 2012: $81-89$

regresi logistik diperoleh nilai signifikansi sebesar 0,000 ( $p<0,05)$. Kesimpulannya bahwa perlu adanya upaya agar tercapainya kemandirian keluarga dalam mengatasi masalah kesehatan di keluarga.

Berdasarkan hasil studi pendahuluan diketahui wilayah kerja Puskesmas Rumbai pada umumnya berada di wilayah Pesisir yang merupakan wilayah perairan, dengan status sosial ekonomi yang bervariasi, sebagian besar sosial ekonomi adalah menengah kebawah, namun masih banyak ditemukan keluarga dengan status sosial ekonomi menengah keatas terutama keluarga yang berada di daerah Kelurahan Limbungan Baru. Hasil wawancara dengan kepala Puskesmas Rumbai, diketahui bahwa Kelurahan Meranti Pandak, seringkali terkena banjir setiap tahunnya, sehingga berisiko tinggi untuk terjadi berbagai masalah kesehatan akibat lingkungan yang tidak sehat, seperti: Diare, DBD, ISPA, Dermatitis, dll. Sedangkan di kelurahan Limbungan Baru berdasarkan hasil pengumpulan data yang dilakukan mahasiswa praktik profesi keperawatan komunitas, keluarga, dan gerontik pada bulan November 2011 didapatkan data masalah kesehatan yang banyak dialami oleh keluarga adalah masalah infeksi pernafasan atas (ISPA, gizi kurang, hipertensi, rematik, dan gastritis)

Data lain yang didapatkan dari hasil wawancara dengan penanggung jawab program kesehatan lansia di Puskesmas Rumbai, adalah tingginya angka masalah kesehatan atau penyakit kronis degeneratif pada lansia, seperti: Hipertensi, Diabetes Melitus, dan Rematik. Tingkat keparahan penyakit ini sangat dipengaruhi oleh kemampuan keluarga mengontrol dan merawat anggota keluarga yang sakit di rumah. Hal ini menunjukkan bahwa belum adanya kemandirian keluarga dalam menjalan fungsi perawatan kesehatan di keluarga. Berdasarkan hasil survey langsung ke pemukiman penduduk di Kelurahan Limbungan baru ditemukan mayoritas keluarga berada pada tingkat kemandirian I (pertama). Rata-rata keluarga hanya mampu mengenal sebagian kecil masalah kesehatan anggota keluarganya dan menerima petugas kesehatan (perawat), sedangkan untuk melakukan upaya pencegahan dan upaya promosi kesehatan belum dilakukan keluarga.

Berdasarkan uraian tersebut, maka peneliti tertarik untuk melakukan penelitian efektifitas pemberian asuhan keperawatan (Askep) keluarga terhadap kemandirian keluarga dalam mengatasi masalah kesehatan di keluarga. 


\section{METODE PENELITIAN}

Desain yang digunakan dalam penelitian ini adalah kuasi eksprimen one group pretest-posttest design yang bertujuan untuk mengetahui pengaruh pemberian asuhan keperawatan keluarga terhadap kemandirian keluarga dalam mengatasi masalah kesehatan keluarga. Sampel dalam penelitian adalah sebanyak 50 keluarga yang memenuhi kriteria inklusi, diantaranya: bersedia menjadi responden, keluarga dengan tipe keluarga inti (Nuclear family) dan tipe keluarga besar (Extended family),serta ada masalah kesehatan di keluarga. Teknik atau cara pengambilan sampel dengan menggunakan metode purposive sampling di wilayah kerja Puskesmas Rumbai dan Karya Wanita. Penelitian ini dilakukan di RW 18 Kelurahan Meranti Pandak, RW 7 dan RW 10 Kelurahan Limbungan Baru. Alat pengumpul data yang digunakan dalam bentuk kuesioner dan panduan observasi yang telah dinyatakan valid dan reliabel, dimana mengacu pada Depkes RI. Item observasi terdiri dari menerima petugas, menerima pelayanan kesehatan sesuai rencana, tahu dan dapat mengungkapkan masalah kesehatan secara benar, memanfaatkan fasilitas pelayanan kesehatan sesuai anjuran, melakukan tindakan pencegahan secara aktif, melakukan tindakan peningkatan kesehatan (promotif) secara aktif. Data diambil 2 kali yaitu sebelum dan sesudah dilakukan Akep keluarga. Analisa data pada penelitian ini bersifat univariat dan bivariat (uji $T$ dependen). Analisa univariat dalam bentuk distribusi frekuensi (\%) dan analisa bivariat guna melihat kemandirian keluarga mengatasi masalah kesehatan di keluarga sebelum dan sesudah dilakukan asuhan keperawatan keluarga $(p<0,005)$.

\section{HASIL DAN PEMBAHASAN}

A. Tingkat Kemandirian Keluarga Sebelum Dilakukan Askep Keluarga dibawah ini merupakan hasil penelitian tentang tingkat kemandirian keluarga sebelum dilakukan Askep Keluarga

Tabel 1. Distribusi Frekuensi Tingkat Kemandirian Keluarga Sebelum Dilakukan Askep Keluarga

\begin{tabular}{|c|c|c|c|}
\hline No & Tingkat Kemandirian (KM) & Jumlah & Persentase \\
\hline 1 & KM 1 & 10 & 20 \\
\hline 2 & KM 2 & 18 & 36 \\
\hline 3 & KM 3 & 21 & 42 \\
\hline 4 & KM 4 Jumlah & 1 & 2 \\
\hline & \multicolumn{2}{|r|}{50} & 100 \\
\hline
\end{tabular}


Vol 7, No 2, Oktober 2012: 81 - 89

Tabel 1 menunjukkan bahwa sebelum dilakukan asuhan keperawatan pada keluarga mayoritas tingkat kemandirian keluarga adalah tingkat kemandirian 3 , yaitu sebanyak 21 keluarga (42\%).

Hal ini disebabkan karena kurangnya pengetahuan keluarga tentang berbagai masalah kesehatan atau penyakit yang dialami oleh semua anggoota keluarga. Selain itu juga masih kurangnya pengetahuan dan kemampuan keluarga dalam melakukan perawatan kesehatan keluarga untuk mencegah dan mengatasi berbagai masalah kesehatan di dalam keluarga. Rendahnya pengetahuan keluarga tersebut disebabkan oleh berbagai faktor, diantaranya: tingkat pendidikan kepala keluarga yang masih rendah, status sosial ekonomi keluarga yang bervariasi, serta keterbatasan tenaga petugas kesehatan dari Puskesmas untuk membina keluarga diwilayah kerjanya. Menurut Notoatmodjo (2007), banyak faktor yang mempengaruhi perilaku kesehatan, diantaranya adalah: faktor internal (pengetahuan, status sosial ekonomi), dan faktor eksternal (dukungan sosial khususnya dari petugas kesehatan). B. Tingkat Kemandirian keluarga setelah dilakukan askep keluarga.

Dibawah ini merupakan hasil penelitian tentang tingkat kemandirian keluarga setelah dilakukan Askep Keluarga

Tabel 2. Distribusi Frekuensi Tingkat Kemandirian Keluarga Setelah Dilakukan Askep Keluarga

\begin{tabular}{|c|c|c|c|}
\hline No & Tingkat Kemandirian (KM) & Jumlah & Persentase \\
\hline 1 & KM 1 & 0 & 0 \\
\hline 2 & KM 2 & 1 & 2 \\
\hline 3 & KM 3 & 14 & 28 \\
\hline 4 & KM 4 Jumlah & 35 & 70 \\
\hline & \multicolumn{2}{|r|}{50} & 100 \\
\hline
\end{tabular}

Tabel 2 menunjukkan bahwa setelah dilakukannya asuhan keperawatan keluarga secara efektif mayoritas tingkat kemandirian keluarga adalah tingkat kemandirian 4, yaitu sebanyak 35 keluarga (70\%).

Hal ini disebabkan karena telah terbinanya keluarga dalam merawat anggota keluarga dengan berbagai masalah kesehatan di rumah melalui penerapan asuhan keperawatan keluarga secara profesional. Dimana dengan dilakukannya asuhan keperawatan keluarga yang profesional, sistematis, kontinu dan berkesinambungan, dapat membantu dalam meningkatkan pengetahuan keluarga dalam menjalankan 5 tugas kesehatan keluarga mulai dari kemampuan keluarga dalam mengenal berbagai masalah kesehatan pada seluruh anggota keluarga, memutuskan tindakan 
keperawatan yang tepat, melakukan perawatan yang tepat jika ada anggota keluarga yang sakit, menciptakan lingkungan keluarga yang mendukung kesehatan, dan mampu memanfaatkan fasilitas kesehatan yang ada (Friedman, 2003). Dengan demikian, diharapkan dapat meningkatkan tingkat kemandirian keluarga dalam mencegah dan mengatasi berbagai masalah kesehatan keluarga.

Menurut Depkes RI (2006), ada beberapa kriteria kemandirian keluarga berrdasarkan tingkat kemandirian (tingkat kemandirian I - IV), diantaranya: menerima petugas kesehatan, menerima pelayanan kesehatan sesuai rencana keperawatan keluarga, keluarga tahu dan dapat mengungkapkan masalah kesehatannya dengan benar, memanfaatkan fasilitas pelayanan kesehatan sesuai anjuran, melakukan tindakan keperawatan sederhana sesuai anjuran, melakukan tindakan pencegahan secara aktif, dan melakukan tindakan promotif secara aktif.

C. Pengaruh asuhan keperawatan keluarga terhadap tingkat kemandirian keluarga Dibawah ini merupakan hasil penelitian tentang rata-rata kemandirian keluarga sebelum dan setelah dilakukan Askep Keluarga

Tabel 3. Distribusi rata-rata Kemandirian Keluarga sebelum dan sesudah Dilakukan Askep Keluarga

\begin{tabular}{|c|c|c|c|c|c|}
\hline Variabel & Mean & SD & SE & P Value & N \\
\hline $\begin{array}{l}\text { Kemandirian Keluarga } \\
\text { sebelum Askep Keluarga }\end{array}$ & 2,26 & 0,803 & 0,114 & & \\
$\begin{array}{l}\text { - Kemandirian Keluarga } \\
\text { sesudah Askep Keluarga }\end{array}$ & 3,68 & 0,513 & 0,073 & 0,000 & 50 \\
\hline
\end{tabular}

Tabel 3 menunjukkan bahwa terdapat pengaruh yang signifikan pemberian Askep keluarga terhadap tingkat kemandirian keluarga dalam mengatasi masalah kesehatan keluarga ( $p$ value $=0,000$ ).

Menurut Friedman (2003), fungsi perawatan kesehatan keluarga bisa tercapai dilihat dari kemampuan keluarga memahami dan melaksanakan lima tugas kesehatan keluarga. Hal ini sangat tergantung dari peran perawat dalam memberikan asuhan keperawatan pada keluarga, sehingga diharapkan keluarga mendapatkan upaya pembinaan dan bimbingan dalam menjalankan lima fungsi perawatan kesehatan keluarga. Upaya pembinaan dan bimbingan kepada keluarga sangat mempengaruhi tercapainya kemandirian keluarga dalam mengatasi berbagai 
Vol 7, No 2, Oktober 2012: 81 - 89

masalah kesehatan di keluarga. Hal ini disebabkan karena Askep keluarga merupakan rangkaian kegiatan transfer ilmu dan kemampuan keluarga mengatasi masalah kesehatan yang ada dengan menggunakan berbagai strategi guna terjadinya perubahan perilaku ke arah yang lebih baik. Strategi atau metode yang digunakan meliputi pendidikan kesehatan menggunakan verbal, psikomotor (praktik) dan afektif untuk melihat sejauh mana kepatuhan keluarga melakukan kegiatan mengatasi masalah kesehatan yang ada di keluarga.

Notoatmodjo (2003) menyatakan bahwa strategi perubahan perilaku adalah dengan memberikan informasi tentang cara menghindari penyakit dan meningkatkan pengetahuan masyarakat. Selanjutnya dengan pengetahuan tersebut dapat menimbulkan kesadaran di antara masyarakat untuk berperilaku sesuai dengan pengetahuan yang dimiliki. Penelitian Basuki (2006) memperlihatkan bahwa metode pendidikan kesehatan mempunyai hubungan yang bermakna dalam peningkatan pengetahuan. Penelitian Basuki ini sesuai dengan hasil pada penelitian ini, dimana rata-rata kemandirian keluarga mengatasi masalah kesehatan sesudah diberikan Askep keluarga (2,26 menjadi 3,68). Rata-rata kemandirian keluarga dalam mengatasi masalah kesehatan di keluarga berada pada tingkat kemandirian ke -4 setelah dilakukan Askep keluarga.

Hasil penelitian ini sejalan dengan hasil penelitian yang dilakukan Parellangi (2012) yang menyatakan adanya pengaruh pelayanan home care terhadap tingkat kemandirian keluarga dalam merawat anggota keluarga dengan pasca Stroke pada kelompok perlakuan didapatkan nilai $p=0,000(p<0,05)$.

\section{SIMPULAN}

Hasil penelitian ini menunjukkan bahwa sebelum dilakukan asuhan keperawatan pada keluarga mayoritas tingkat kemandirian keluarga adalah tingkat kemandirian 3, yaitu sebanyak 21 keluarga (42\%), setelah dilakukannya asuhan keperawatan keluarga secara efektif mayoritas tingkat kemandirian keluarga adalah tingkat kemandirian 4, yaitu sebanyak 35 keluarga (70\%). Dari hasil analisa bivariat menggunakan uji $\mathrm{T}$ dependent menunjukkan bahwa terdapat pengaruh yang signifikan pemberian Askep keluarga terhadap tingkat kemandirian keluarga dalam mengatasi masalah kesehatan keluarga, dengan $p$ value $=0,000$. Perlu dilakukan Askep keluarga guna membantu keluarga dalam mengatasi masalah kesehatan tang ada di dalam keluarga. 


\section{DAFTAR PUSTAKA}

Basuki, 2006. Efektifitas metoda penyuluhan dalam peningkatan pengetahuan tentang hygiene pada murid SD KecamatanSeberida Kabupaten Indragiri Hulu Tesis, Medan Fakultas Kesehatan Masyarakat Universitas Sumatra Utara

Dinkes Jakarta. 2004. Pelatihan asuhan keperawatan keluarga. PPNI-Dinkes Jakarta

Depkes RI 2008. Riskesdas 2007. Badan Penelitian dan Pengembangan, Departemen Kesehatan RI. Jakarta

DepKes Jakarta. 2008. Pedoman kegiatan perawat kesehatan masyarakat di Puskesmas. Jakarta

Friedman, M.M, Bowden, V.R, and Jones, E.G. 2003. Family nursing :research theory, practice. $5^{\text {th }}$ edition. Prentice Hall, New Jersey.

Friedman, M.M. 2003. Family nursing : research, theory \& practice, $4^{\text {th }}$ ed. USA : Appleton and Lange.

Misbach. 2005. Stroke, risiko utama hipertensi. http://www.indomedia.com.

Nursalam. 2003. Konsep dan penerapan metodologi penelitian ilmu keperawatan. Salemba medika: Jakarta

Notoatmodjo, S. 2003. Pendidikan dan perilaku kesehatan. Rineka Cipta, Jakarta 2007. Promosi kesehatan \& ilmu perilaku. Rineka cipta: Jakarta

Netty, H. 2000. Asuhan Keperawatan Keluarga. FIK - UI

Parellangi. 2012. Pengaruh pelayanan home care terhadap tingkat kemandirian keluarga dalam merawat anggota keluarga dengan pasca stroke di kota Provinsi Kalimantan

Timur. http://media.unpad.ac.id/thesis/220120/2010/220120100001 c 5140.pdf

Purnomo, H., 2009, Pencegahan dan pengobatanpPenyakit yang paling mematikan, Buana Pustaka, Yogyakarta

Suhartini R. 2006. Faktor-faktor yang mempengaruhi kemandirian orang lanjut usia (studi kasus di kelurahan Jambangan) . http://damandiri.or.id/detail.php?id=340

tkpk-riau.org 2009. Jumlah penduduk miskin. Diakses dari situs http://tkpkriau.org/content/view/32/63/ pada tanggal 29 Januari 2010

WHO. 2001. Pengendalian hipertensi. ITB: Bandung

Zulfitri.R, Agrina, Herlina. (2011). Gambaran pelaksanaan fungsi perawatan kesehatan keluarga di wilayah kerja Puskesmas Rumbai. Penelitian Laboratorium tahun 2012. 